\title{
PERUBAHAN AKTIVITAS DAN PENYESUAIAN RUANG PADA RUMAH TINGGAL SEBAGAI RESPON TERHADAP PANDEMI COVID19
}

\author{
Activity Changes and Space Adjustments in Residential Houses as a Response to Covid19 Pandemic
}

\author{
Theresia Emi Rahayu ${ }^{1}$
}

1)Program Studi Pascasarjana Arsitektur, Fakultas Teknik Universitas Atmajaya Yogyakarta (theresiaemi.te@gmail.com)

\begin{abstract}
ABSTRAK
Salah satu upaya untuk mengurangi penyebaran virus Covid-19 adalah dengan membatasi aktivitas penghuni di luar rumah. Fungsi rumah menjadi lebih bervariasi karena kegiatan yang berlangsung di dalam rumah tinggal tidak hanya beristirahat, makan, dan membersihkan diri, namun juga bekerja, sekolah, beribadah dan rekreasi. Perubahan atau penyesuaian pada rumah tinggal dilakukan untuk mewadahi perubahan aktivitas tersebut. Tujuan dari penelitian ini adalah untuk mengetahui penyesuaian pada rumah tinggal yang dilakukan oleh masyarakat, sehingga bisa digunakan sebagai acuan untuk perencanaan rumah tinggal selanjutnya. Metode yang dilakukan untuk mengumpulkan data yaitu dengan menggunakan kuesioner googleform yang disebarkan pada responden di Yogyakarta maupun di luar Yogyakarta pada bulan Februari tahun 2021, kemudian dianalisis dengan metode korelasi dan diuraikan secara deskriptif. Kesimpulan yang didapatkan yaitu sebagian besar responden menerapkan sistem bekerja secara kombinasi atau berselang-seling antara WFH (Work from Home) dan WFO (Work from Office), sedangkan anak usia sekolah hampir keseluruhannya belajar dari rumah. Berdasarkan jenis pekerjaan, responden dengan pekerjaan wiraswasta tidak ada perubahan lokasi bekerja. Aktivitas sosial yang sebelumnya dilakukan di luar rumah, berubah menjadi dihilangkan atau dilakukan secara daring. Penyesuaian pada rumah tinggal untuk mewadahi perubahan aktivitas ini sebagian besar dilakukan oleh responden dengan status rumah milik sendiri, meskipun kondisi rumah sudah dianggap mendukung kesehatan penghuninya.
\end{abstract}

Kata-kata kunci: Perubahan Aktivitas, Penyesuaian Ruang, Pandemi Covid19, Perencanaan Rumah Tinggal

\section{ABSTRACT}

To limit the activities of residents outside their home is an effort to reduce the Covid-19 virus from spreading. House function becomes more varied because the activities in the household are not only resting, eating, and take a bath, but also working, schooling, worship, and recreation. Changes or adjustments to residential houses are made to accommodate these changes in activity. The purpose of this study was to find out the adjustments to residential homes, so that it could be used as a reference fot future residential planning. The method used to collect data is by using googleform questionnaire distributed to respondents in Yogyakarta and outside Yogyakarta in February 2021, then analyzed by the correlation method and described descriptively. The conclusion obtained is that most of the respondents work in combination or alternately between WFH (Work from Home) and WFO (Work from Office), while almost all school-age children study from home. Based on the type of work, respondents with self-employed jobs did not change their work location. Social activities that were previously carried out outside the home have been removed or carried out online. Adjustments to the housing to accommodate changes in activity were mostly carried out by respondents who owned their house, even though the condition of the house was already considered healthy.

Keywords: Activity Changes, Space Adjustment, Covid19 Pandemic, Residential House Planning

\begin{tabular}{lll}
\hline Article History & & \\
\hline Diterima (Received) & $:$ & $08-11-2021$ \\
Diperbaiki (Revised) & $:$ & $23-12-2021$ \\
Diterima (Accepted) & $:$ & $25-12-2021$
\end{tabular}




\section{PENDAHULUAN}

Penyebaran virus Covid-19 bermula pada akhir tahun 2019 di Kota Wuhan, Provinsi Hubei, China. Pada tanggal 11 Maret 2020 ditetapkan sebagai pandemi Covid-19 karena telah menyebar ke berbagai benua dan negara, dengan tingkat penyebaran relatif tinggi. Tanggal 14 Maret 2020, pemerintah Indonesia menetapkan pandemi Covid19 sebagai bencana nasional (Thorik, 2020). Untuk menekan tingkat penyebaran virus, diberlakukan kebijakan jaga jarak atau physical distancing (Saleh, 2020). Kebijakan ini membatasi aktivitas masyarakat di luar ruangan dan disarankan untuk tetap di rumah (Ardella, 2020). Bagi anak usia sekolah, program belajar dari rumah dilakukan secara mandiri dengan didampingi orangtua (Yulianingsih et al., 2020).

Perubahan pola kerja menjadi remote working atau work from home (WFH) merupakan salah satu himbauan dari pemerintah yang secara tidak langsung mempengaruhi dinamika kehidupan di keluarga (Suryaningtyas, 2020). Bekerja atau belajar dari rumah dilakukan dengan aplikasi web conference untuk menggantikan proses tatap muka (Kurniasari et al., 2020). Seluruh kegiatan yang dilakukan di rumah tanpa diimbangi aktivitas fisik akan mempengaruhi kesehatan, sehingga disarankan untuk berolahraga di rumah agar tetap sehat (Hammami et al., 2020). Kegiatan berkebun di rumah sebagai aktivitas fisik dapat memberikan efek positif pada kesehatan mental, fisik, dan lingkungan yang penting selama masa pandemi Covid-19 (Katz, 2013). Berkebun di rumah dengan menanam tanaman pangan juga meningkat selama pandemi (Mullins et al., 2021). Dapat disimpulkan bahwa perubahan aktivitas yang terjadi di rumah tinggal selama pandemi antara lain bekerja dari rumah (work from home), belajar dari rumah (learning from home), berolahraga dan berkebun. Perubahan aktivitas ini terjadi selain karena menaati kebijakan pemerintah, namun juga upaya masyarakat untuk tetap sehat dan terhindar dari virus Covid-19.

\section{KAJIAN PUSTAKA}

Rumah tidak hanya bangunan yang berfungsi sebagai tempat berlindung dari cuaca, namun merupakan hunian yang digunakan untuk beristirahat, bercengkerama dengan anggota keluarga, dan memberikan kenyamanan fisiologis dan psikologis. Rumah diharapkan dapat memenuhi kebutuhan akan rasa aman dan nyaman, serta berfungsi sebagai tempat untuk bersosialisasi.
Berdasarkan Undang-undang Bangunan Gedung No.28 Tahun 2002, bangunan gedung memiliki beberapa fungsi antara lain fungsi sebagai rumah tinggal atau hunian, fungsi keagamaan, tempat usaha, fasilitas sosial dan budaya, serta fungsi khusus. Bangunan gedung sebagai rumah tinggal meliputi bangunan untuk hunian tunggal yaitu rumah yang letaknya terpisah dari rumah lainnya, rumah tinggal deret atau rumah yang susunannya berjajar seperti pada perumahan, rumah susun, dan rumah tinggal sementara (Undang-undang Bangunan Gedung, 2002).

Berdasarkan Undang-undang No.1 Tahun 2011 Tentang Perumahan dan Kawasan Permukiman, rumah adalah bangunan gedung yang berfungsi sebagai hunian yang layak, sarana pembinaan keluarga, cerminan harkat dan martabat penghuninya, serta aset bagi pemiliknya (UndangUndang RI No.1 Tentang Perumahan Dan Kawasan Permukiman, 2011).

Dalam Keputusan Menteri Kesehatan RI Nomor: 829/Menkes/SKNII/1999 tentang Persyaratan Kesehatan Permukiman (Kementerian Kesehatan, 1999), persyaratan kesehatan rumah tinggal telah ditentukan, antara lain:

- Lokasi lingkungan perumahan memiliki kualitas udara yang bersih, jauh dari kebisingan dan getaran, memiliki kualitas tanah yang baik, air tanah layak minum dan mencukupi untuk kebutuhan sehari- hari. Selain itu memiliki sarana dan prasarana lingkungan yang memadai, tidak ada binatang penular penyakit, memiliki ruang terbuka hijau serta pencahayaan yang memadai.

- Rumah tinggal dibangun menggunakan material yang tidak membahayakan kesehatan, komponen rumah seperti lantai harus mudah dibersihkan, memiliki ventilasi yang memadai, penataan ruang di dalam rumah memenuhi kebutuhan penghuni, memiliki sarana pengolahan limbah agar tidak mencemari sumber air.

- Kepadatan hunian untuk ruang tidur minimal $8 \mathrm{~m}^{2}$ untuk satu orang.

Rumah tinggal harus dapat melindungi penghuninya dari cuaca dan menjaga kesehatan penghuninya. Oleh karena itu diperlukan ventilasi udara yang baik, kehangatan di dalam ruangan, memiliki kelembaban udara yang nyaman dan penerangan di dalam ruangan memadai (Neufert, 1996). Peruangan di dalam hunian harus dapat mewadahi aktivitas dan kebutuhan. Hunian harus memiliki ruang tidur untuk tempat beristirahat, dapur dengan ruang makan, ruang tamu, dan kamar mandi 
Journal of Architecture - University of Muhammadiyah Aceh Vol: 11 | No: 2 (2021): December

(Kementerian Pekerjaan Umum dan Perumahan Rakyat, 2017).

Kenyamanan pada hunian tidak hanya berdasarkan pada pemenuhan kebutuhan ruang saja, namun juga dipengaruhi oleh aspek fisik dan non-fisik. Aspek fisik dipengaruhi oleh lingkungan atau lokasi hunian, sedangkan aspek non-fisik dipengaruhi oleh budaya, sosial, dan kondisi ekonomi penghuni (Sabaruddin, 2018).

Rumah yang nyaman sangat diperlukan mengingat hampir semua kegiatan sehari-hari dilakukan di dalam rumah selama pandemi Covid-19 yang telah berlangsung sejak awal tahun 2020 . Terjadi perubahan aktivitas di dalam hunian, yaitu perubahan sistem kerja dari sebelumnya tatap muka di kantor menjadi bekerja dari rumah (working from home) dan belajar dari rumah (learning from home) diterapkan untuk menekan angka penyebaran virus Covid-19.

\section{METODOLOGI}

Penelitian ini dilakukan dengan mengumpulkan data melalui googleform pada bulan Februari tahun 2021 karena di masa pandemi Covid19 tidak memungkinkan untuk dilakukan survey langsung. Data yang didapatkan dianalisis dengan metode korelasi dan diuraikan secara deskriptif. Penelitian ini bertujuan untuk mengetahui penyesuaian pada rumah tinggal yang dilakukan oleh masyarakat sebagai respon terhadap situasi pandemi Covid19.

\section{HASIL DAN PEMBAHASAN}

Berdasarkan data yang diperoleh dari kuesioner googleform, didapatkan karakteristik responden adalah sebagai berikut:

Tabel 1: Karakteristik Responden

\begin{tabular}{clll}
\hline No. & Keterangan & \multicolumn{1}{c}{ Indikator } & Jumlah \\
\hline 1 & Lokasi & DIY & 143 \\
& & Luar DIY & 289 \\
\hline 2 & Usia & $<23$ tahun & 41 \\
& & $24-60$ tahun & 369 \\
& & $>61$ tahun & 22 \\
\hline 3 & Jenis & Laki- laki & 235 \\
& kelamin & Perempuan & 197 \\
\hline 4 & Pekerjaan & PNS/TNI/POLRI & 61 \\
& & Pegawai Swasta & 198 \\
& & Wirausaha & 66 \\
& & Pensiunan & 24 \\
& & IRT/ tidak bekerja & 40 \\
\hline
\end{tabular}

Sumber : Analisis, 2021

\begin{tabular}{ccll}
\hline & & Pelajar & 43 \\
\hline 5 & Pendidikan & SMA/sederajat & 62 \\
& & Diploma & 29 \\
& & S1 & 223 \\
& & S2 & 100 \\
& & S3 & 18 \\
\hline 6 & Status & Rumah sendiri & 327 \\
& Rumah & Bukan rumah & 105 \\
& & sendiri & \\
\hline 7 & Jumlah & $<3$ orang & 73 \\
& penghuni & 3-5 orang & 284 \\
& & $>5$ orang & 75 \\
\hline
\end{tabular}

Sumber: Analisis, 2021

Karakteristik responden dilihat dari lokasi rumah, usia, jenis kelamin, jenis pekerjaa, pendidikan terakhir, status rumah tinggal, dan jumlah penghuni. Total responden adalah 432 orang dengan mayoritas usia produktif $24-60$ tahun (85.4\%). Jenis pekerjaan didominasi oleh pegawai swasta 198 orang $(45.8 \%)$. Status kepemilikan rumah sebanyak $327(75.7 \%)$ berstatus milik sendiri, dengan jumlah penghuni antara 3-5 orang sebanyak 284 (65.7\%).

Berdasarkan hasil kuesioner dapat dilihat bahwa kegiatan penghuni rumah tinggal mengalami perubahan ritme antara sebelum dan selama pandemi Covid19.

\section{Tabel 2: Bekerija Sebelum dan Selama Pandemi}

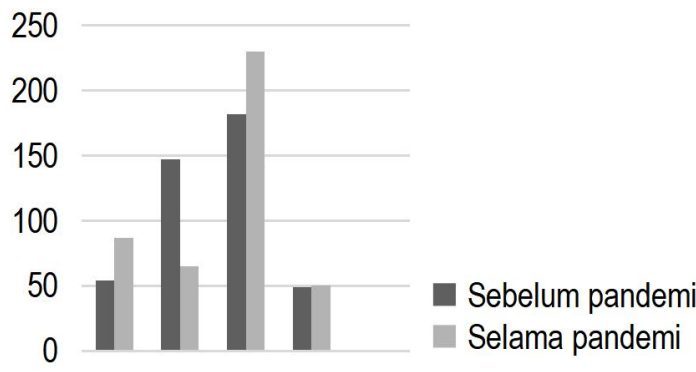

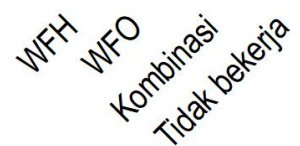

Tabel 2 menunjukkan bahwa selama pandemi terjadi kenaikan jumlah responden yang berkerja dari rumah, dari 54 orang (12.5\%) menjadi 87 orang (20.1\%). Sedangkan responden yang berkerja dari kantor berkurang dari 147 orang (34\%) sebelum pandemi menjadi hanya 65 orang $(15 \%)$ selama pandemi. 
Rumôh

Journal of Architecture - University of Muhammadiyah Aceh

Vol: 11 | No: 2 (2021): December

Tabel 3: Pengaruh Karakteristik Responden Terhadap Perubahan Aktivitas dan Penyesuaian Ruang

\begin{tabular}{|c|c|c|c|c|c|c|c|c|}
\hline & \multirow[t]{2}{*}{ Variabel } & $\begin{array}{l}\text { Lokasi } \\
\text { Rumah }\end{array}$ & Usia & $\begin{array}{c}\text { Jenis } \\
\text { Kelamin }\end{array}$ & Pekerjaan & Pendidikan & $\begin{array}{l}\text { Status } \\
\text { Rumah }\end{array}$ & $\begin{array}{c}\text { Jumlah } \\
\text { Penghuni }\end{array}$ \\
\hline & & \multicolumn{7}{|c|}{ Approximate Significance } \\
\hline \multirow{5}{*}{$\begin{array}{l}\text { Aktivitas } \\
\text { Sebelum } \\
\text { Pandemi }\end{array}$} & Bekerja & 0.014 & 0.000 & 0.010 & 0.000 & 0.000 & 0.189 & 0.064 \\
\hline & Jam kerja & 0.658 & 0.000 & 0.589 & 0.000 & 0.000 & 0.526 & 0.071 \\
\hline & Belajar & 0.223 & 0.231 & 0.009 & 0.456 & 0.009 & 0.695 & 0.914 \\
\hline & Aktivitas lingkungan & 0.662 & 0.067 & 0.071 & 0.125 & 0.176 & 0.323 & 0.871 \\
\hline & Mobilitas & 0.162 & 0.208 & 0.696 & 0.000 & 0.022 & 0.336 & 0.093 \\
\hline \multirow{5}{*}{$\begin{array}{l}\text { Aktivitas } \\
\text { Selama } \\
\text { Pandemi }\end{array}$} & Bekerja & 0.014 & 0.000 & 0.016 & 0.000 & 0.000 & 0.022 & 0.213 \\
\hline & Jam kerja & 0.417 & 0.302 & 1.000 & 0.033 & 0.399 & 0.760 & 0.168 \\
\hline & Belajar & 0.085 & 0.799 & 0.023 & 0.267 & 0.622 & 0.031 & 0.164 \\
\hline & Aktivitas lingkungan & 0.243 & 0.068 & 0.454 & 0.023 & 0.171 & 0.172 & 0.796 \\
\hline & Mobilitas & 0.345 & 0.509 & 0.199 & 0.002 & 0.267 & 0.212 & 0.954 \\
\hline \multirow{3}{*}{$\begin{array}{l}\text { Kondisi } \\
\text { Hunian }\end{array}$} & Bekerja & 0.718 & 0.580 & 0.621 & 0.116 & 0.001 & 0.002 & 0.416 \\
\hline & Belajar & 0.417 & 0.200 & 0.804 & 0.593 & 0.177 & 0.000 & 0.031 \\
\hline & Isolasi mandiri & 0.563 & 0.222 & 0.377 & 0.739 & 0.055 & 0.001 & 0.361 \\
\hline \multirow{4}{*}{ Penyesuaian } & Bekerja & 0.199 & 0.045 & 0.157 & 0.043 & 0.937 & 0.542 & 0.900 \\
\hline & Belajar & 0.042 & 0.019 & 0.397 & 0.015 & 0.751 & 0.163 & 0.714 \\
\hline & Aktivitas lingkungan & 0.148 & 0.035 & 0.733 & 0.133 & 0.015 & 0.812 & 0.402 \\
\hline & Isolasi mandiri & 0.647 & 0.011 & 0.687 & 0.029 & 0.991 & 0.013 & 0.972 \\
\hline \multirow{3}{*}{ New Normal } & Menerima tamu & 0.098 & 0.606 & 0.178 & 0.389 & 0.129 & 0.595 & 0.606 \\
\hline & Rumah sehat & 0.187 & 0.077 & 0.728 & 0.530 & 0.077 & 0.000 & 0.411 \\
\hline & Isolasi mandiri & 0.775 & 0.143 & 0.936 & 0.647 & 0.244 & 0.000 & 0.563 \\
\hline
\end{tabular}

Catatan: Korelasi signifikan pada level $<0.05$.

Hasil analisis korelasi terhadap karakteristik responden dan variabel penelitian, didapatkan hasil bahwa lokasi rumah responden berpengaruh pada aktivitas bekerja dan belajar dari rumah. Penyesuaian untuk keperluan belajar dari rumah diterapkan oleh 190 responden (44\%).

Dari segi usia, data responden yang didapatkan mayoritas adalah responden dengan usia produktif dan usia sekolah, sehingga aktivitas sebelum dan selama pandemi sangat dipengaruhi oleh kebijakan pemerintah. Penyesuaian pada rumah tinggal untuk bekerja, belajar, aktivitas lingkungan, dan isolasi mandiri berkaitan erat dengan usia responden. Adaptasi pada hunian untuk bekerja dari rumah diterapkan oleh 188 responden (43.5\%) yaitu responden dengan usia produktif yang menerapkan sistem bekerja dari rumah (WFH) dan kombinasi antara bekerja dari rumah dan dari kantor.

Jenis kelamin responden hanya berkaitan erat dengan perubahan aktivitas sebelum dan selama pandemi, yaitu aktivitas bekerja dan belajar, sedangkan untuk penyesuaian pada rumah tinggal tidak dipengaruhi oleh jenis kelamin responden.

Pekerjaan responden berpengaruh pada beberapa variabel penelitian, antara lain lokasi bekerja, jadwal kerja, aktivitas lingkungan, dan mobilitas keluar rumah. Kecuali responden dengan pekerjaan wiraswasta tidak ada perubahan lokasi bekerja dari sebelum dan selama pandemi. Pekerjaan responden tidak berpengaruh terhadap penyesuaian rumah tinggal untuk aktivitas lingkungan. Aktivitas lingkungan yang dimaksud antara lain arisan, pertemuan warga, rapat lingkungan, dan kegiatan sejenis. Aktivitas lingkungan selama pandemi dianjurkan untuk ditunda atau dilaksanakan secara daring, namun sebanyak 144 responden (33.3\%) pernah melakukan penyesuaian pada rumah tinggal untuk keperluan aktivitas warga lingkungan.

Tingkat pendidikan terakhir responden selain berpengaruh pada aktivitas sebelum dan selama pandemi Covid19, juga berpengaruh pada penyesuaian yang dilakukan pada rumah tinggal untuk aktivitas lingkungan. Semakin tinggi tingkat pendidikan, lebih banyak responden yang tidak melakukan penyesuaian pada rumah tinggal, karena mengurangi interaksi dengan orang banyak.

Kegiatan belajar dari rumah menggunakan platform digital membutuhkan penyesuaian pada rumah tinggal. Kondisi rumah responden yang dianggap memadai untuk belajar dari rumah sebanyak $215(49.7 \%)$ dengan status rumah milik sendiri, dan sebanyak 44 (10\%) bukan rumah milik sendiri. Penyesuaian pada rumah tinggal untuk 
keperluan belajar dari rumah dilakukan oleh 190 responden (44\%). Sehingga bisa disimpulkan bahwa responden berusaha agar rumah tinggal bisa digunakan untuk belajar dari rumah dengan lebih nyaman.

Jumlah penghuni pada rumah tinggal responden berkaitan erat dengan kondisi rumah untuk belajar dari rumah. Dengan jumlah penghuni yang belajar dari rumah lebih banyak, maka diperlukan pembagian ruang dengan luasan yang lebih besar agar memadai untuk aktivitas belajar dari rumah.

\section{KESIMPULAN}

Pembatasan aktivitas di luar rumah sebagai upaya untuk mengurangi penyebaran virus Covid-19 mengakibatkan intensitas kegiatan di dalam rumah meningkat. Sebagian besar responden menerapkan sistem bekerja secara kombinasi atau berselangseling antara WFH dan WFO (Work from Office), sedangkan anak usia sekolah hampir keseluruhannya belajar dari rumah. Berdasarkan jenis pekerjaan, responden dengan pekerjaan wiraswasta tidak ada perubahan lokasi bekerja. Aktivitas sosial yang sebelumnya dilakukan di luar rumah, berubah menjadi dihilangkan atau dilakukan secara daring. Penyesuaian pada rumah tinggal untuk mewadahi perubahan aktivitas ini sebagian besar dilakukan oleh responden dengan status rumah milik sendiri, meskipun kondisi rumah sudah dianggap mendukung kesehatan penghuninya.

Perencanaan rumah tinggal perlu memperhatikan beberapa variabel yang sangat berpengaruh pada hunian, antara lain usia penghuni, pekerjaan, dan jumlah penghuni. Rumah tinggal yang diperuntukkan bagi penghuni usia produktif berbeda dengan penghuni yang sudah pensiun, karena tidak membutuhkan ruang khusus untuk bekerja dan belajar dari rumah.

Pekerjaan penghuni juga berpengaruh pada perencanaan rumah tinggal, karena penghuni dengan pekerjaan wiraswasta dan penghuni yang bekerja sebagai pegawai memiliki ritme dan lokasi kerja yang berbeda. Selama pandemi pegawai swasta maupun pemerintah menerapkan sistem bekerja dari rumah (WFH) dan kombinasi antara bekerja dari rumah dan dari kantor, sementara wiraswasta tidak menerapkan sistem kerja serupa.

Jumlah penghuni berpengaruh pada jumlah ruang yang dibutuhkan untuk beraktivitas di rumah. Penghuni yang memiliki anak dengan usia sekolah lebih dari satu akan membutuhkan luasan ruang belajar yang lebih besar.

\section{DAFTAR PUSTAKA}

Ardella, K. B. (2020). Risiko Kesehatan Akibat Perubahan Pola Makan Dan Tingkat Aktivitas Fisik Selama Pandemi Covid-19. Jurnal Medika Hutama, 02(01), 292-297.

Hammami, A., Harrabi, B., Mohr, M., \& Krustrup, P. (2020). Physical activity and coronavirus disease 2019 (COVID-19): specific recommendations for home-based physical training. Managing Sport and Leisure, O(0), 16.https://doi.org/10.1080/23750472.2020.1757 494

Katz, H. (2013). Crisis Gardening: Addressing Barriers to Home Gardening during the COVID-19 Pandemic. Journal of Chemical Information and Modeling, 53(9), 1689-1699.

Kementerian Kesehatan. (1999). Keputusan Menteri Kesehatan Nomor 829/Menkes/Sk/Vii/1999 Tentang Persyaratan Kesehatan Perumahan. Jakarta.

Kementerian Pekerjaan Umum dan Perumahan Rakyat. (2017). Dasar-dasar Rumah Sehat. Jakarta

Kurniasari, A., Pribowo, F. S. P., \& Putra, D. A. (2020). Analisis Efektivitas Pelaksanaan Belajar Dari Rumah (Bdr) Selama Pandemi Covid-19. Jurnal Review Pendidikan Dasar: Jurnal Kajian Pendidikan Dan Hasil Penelitian, 6(3), 1-8.

Mullins, L., Charlebois, S., \& Finch, E. (2021). Home Food Gardening in Canada in Response to the COVID-19 Pandemic.

Neufert, E. (1996). Data Arsitek (P. W. Indarto (ed.); 33 rd ed.). Erlangga.

Indonesia. (2011). Undang-undang Republik Indonesia Nomor 1 Tahun 2011 tentang Perumahan dan Kawasan Permukiman. Jakarta.

Indonesia. (2002). Undang-Undang Republik Indonesia Nomor 28 Tahun 2002 tentang Bangunan Gedung. Jakarta

Sabaruddin, A. (2018). Hakekat Hunian Vertikal di Perkotaan. Urbanisasi Dan Pengembangan Perkotaan, 10-23.

Saleh, M. (2020). Merdeka Belajar di Tengah Pandemi Covid-19. Prosiding Seminar Nasional Hardiknas, 1, 51-56. http://proceedings.ideaspublishing.co.id/index. php/hardiknas/article/view/8

Suryaningtyas, D. (2020). Bekerja dari rumah: implementasinya pada U-Learning selama pandemi virus Covid-19. Jurnal Ekonomi 
Journal of Architecture - University of Muhammadiyah Aceh Vol: 11 | No: 2 (2021): December

Modernisasi, $\quad$ 16(2), 73-81. https://doi.org/10.21067/jem.v16i2.4837

Thorik, S. H. (2020). Efektivitas Pembatasan Sosial Berskala Besar Di Indonesia Dalam Penanggulangan Pandemi Covid-19. Jurnal Adalah: Buletin Hukum Dan Keadilan, 4(1), 115-120.

Yulianingsih, W., Suhanadji, S., Nugroho, R., \& Mustakim, M. (2020). Keterlibatan Orangtua dalam Pendampingan Belajar Anak selama Masa Pandemi Covid-19. Jurnal Obsesi: Jurnal Pendidikan Anak Usia Dini, 5(2), 11381150. https://doi.org/10.31004/obsesi.v5i2.740

\section{Kutipan Artikel}

Rahayu, T. E. (2021), Perubahan Aktivitas Dan

Penyesuaian Ruang Pada Rumah Tinggal Sebagai

Respon Terhadap Pandemi Covid19, Rumoh, Vol:

11, No: 2, Hal: 49-54: Desember.

DOI: http://doi.org/10.37598/rumoh.v11i2.143 